cussion showed that this technique had great sensitivity and could well be applied to short-lived species.

The credit for the success of the meeting must be shared between the organizers and the authors of the nineteen papers presented, which dealt with very recent advances in fields that were, almost without exception, completely unknown ten years ago.

$$
\text { B. A. 'I HRUSH }
$$

\section{INSPECTION OF INDUSTRIAL POLLUTION IN BRITAIN REPORT FOR 1955}

T HE ninoty-second report on alkali, etc., works in England and Wales and in Scotland by the chief inspectors, covering 1955*, records 921 works in England and Wales registered under the Act at the end of the year, operating 1,794 processes, which is a decroase of six in the number of works and an increase of ten in the number of processes. The 3,894 visits and inspections made during the year included 165 special visits by the chief and deputy chief inspectors; of the total, 521 visits were to or in connexion with works not registered under the Act, and a further 60 visits were to or in connexion with colliery spoil-banks. During the inspections, 2,057 quantitative analyses were made of gases evolved from processes in operation, and 827 special samples were submitted for detailed examination to the Government Chemist. Complaints and requests for technical advice and assistance involved a hundred registered and ninety-four non-registered works, the corresponding figures for 1954 being seventy and ninety, respectively ; the increase is attributed not to deteriorated conditions but to a greater public awareness of the desirability of cleaner air. During the past few years there has been an increase in what are conveniently termed "area complaints", the complaint being directed against emissions from a highly industrial area or one of intensive production, such as Trafford Park, Manchester, and the Thamesside cement area, rather than against that from individual works.

On twenty-one occasions the total acidity of gases escaping to the atmosphere exceeded the statutory limits, and a further twenty-seven infractions related to failure to use "best practicable means". Since on formal notification of infraction suitable action ensued, there was no occasion to institute proceedings. Visits were paid both to the oil-fired Bankside and the coal-fired Battersea electricity generating stations, both of which are in London, to assess the efficiency of the installations for washing flue gas. While the position at Bankside was most satisfactory, the problem at Battersea is more difficult and has to contend with a doubling of the ash content of the coal since before 1939 .

The high demand for cement has continued, and all kilns have operated at full output even when their associated dust-arrestment plants are undergoing repair, so that it was not surprising, especially in view of the fine summer, that there were

- Ministry of Housing and Local Government; Department of Health for Scotland. Alkali, etc., Works Regulation Act, $190 \mathrm{f}$, and Alkali, etc., Works Orders 1928-1050. Alkali, etc., Works Regulations (Scotland) Acts, 1906 and 1951 . Ninety-second Annual Report on Alkali. etc. Works by the Chief Inspectors, 1955. Pp. 51. (London: H.M.S.O., 1956.) 2s. net. complaints from most cement-making areas. The inspectorate continued its general policy of ensuring that all de-dusting plant is kept in as efficient a state as possible, that shut-downs are kept to the absolute minimum and that standards of supervision and "housekeeping" are as high as possible. The operation and maintenance of electrical precipitators still give real difficulty at many works. The production of sulphuric acid as monohydrate reached a record in Britain of 1,899,000 tons, an increase of 61,000 tons over 1954, and there was a spectacular increase in the usage of anhydrite for the dual production of sulphuric acid and cement clinker-from 177,000 tons in 1954 to 382,000 tons-and this process involves a serious problem of mist in the final escapes to air.

The Chief Inspector for Scotland reports no change in the number of works (82) registered under the Acts ; but the number of processes operated increased by three to 119 . On the 195 visits made to registered works, 92 chemical tests of flue emission were made involving the analysis of 116 samples, 14 by the Government Chemist; a further 166 visits were made which were not directly related to the provisions of the Acts. The Chief Inspector remarks that recent research has thrown more light on the dispersal of gases and dust from chimneys, and it seems desirable that the results of this work should be applied more generally, if only to test their validity; he cites an instance in which recently published work on dispersal of dust from high chimneys was particularly useful in connexion with dust emission from a power station in the west of Scotland which is fired with pulverized fue'.

\section{BIRD SEMANTICS}

$\mathrm{M}$ OST birds have a rudimentary language. A crow, for example, gathers its flock by uttering a distinctive 'assembly call' and dieperses it by squawking un 'alarm call'. The flock will respond to tape recordings of these calls just as it does to the cries of a live bird.

Two research groups, one in the United States, the other in France, recently exchanged tapes on which they had recorded the calls of their native crows. Their object was to learn whether French 'crows' (rooks, jackdaws and carrion crows) would understand the language of the American eastern crow, and vice versa (Sci. Amer., August 1956). Ronsting French 'crows' consistently ignored the alarm call of American crows; but more than half the French birds were aroused by the broadcast of an American 'gathering' call. American crows were wholly unmoved by the plaintive cries of nestling rooks or the strident assembly call of adult jackdaws-commands which all three species of French crow invariably oley.

In a further experiment, the French investigators broadcast the food-finding and alarm calls of the American herring gull, a bird that also dwells on French coasts. The French gulls paid no heed to the American calls. From these experiments the investigators concluded that birds learn the language of their kind from older birds of their own group. The investigators included R.-G. Busnel, J. Giban and $\mathrm{Ph}$. Gramet, of the French National Institute for Agricultural Research; the Americans were Hubert and Mabel Frings and J. Jumber, of Pennsylvania State University and the Mount Desert Island Biological Laboratory. 